\title{
WILLIAM RUSSELL ANDERSON (1942-2013)
}

William Russell Anderson, world authority on the large, primarily Neotropical family Malpighiaceae, died on November 2, 2013, in Ann Arbor, Michigan, U.S.A. He was born on September 25, 1942, in Tucson, Arizona. He graduated from Duke University (1964) with a B.S. degree in botany (Phi Beta Kappa, Woodrow Wilson Fellow) and completed his education with the M.S. (1965) and Ph.D. (1971) degrees in botany from the University of Michigan. He is survived by his wife Christiane Eva (Seidenschnur) Anderson and his daughter Rebecca Christiane; his son Russell William preceded him in death.

Bill began his career as Associate Curator at the Herbarium of the New York Botanical Garden in 1971. He joined the faculty of the Department of Botany and the University Herbarium in 1974 as Assistant Professor and Assistant Curator and was promoted to Associate Professor and Curator (1979) and Professor and Curator (1986). He also served a long term as Director of the University Herbarium (1986-1999). Although he retired in 2002, Bill

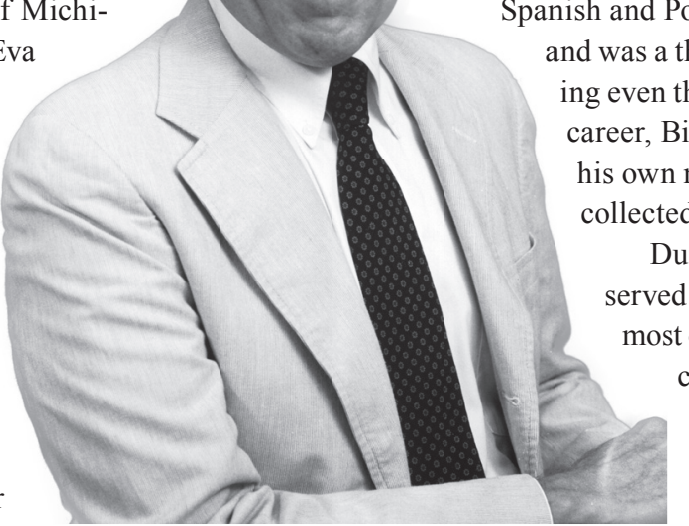

William Russell Anderson. Portrait taken in 1996 by David Bay.

Bill always considered field work an important element of his research, and conducted his first major trip to Jamaica in the summer of 1963 as an undergraduate, followed by a field season in Hawaii (1964) and a second one in Jamaica (1966). Nearly every year afterwards until 2002, Bill conducted field work for extended periods of time. He led eight field trips in Brazil, eleven in Mexico, three in Costa Rica, and two in Argentina and Venezuela; he also visited Colombia and other places in the Neotropics where Malpighiaceae are diverse. In addition to French and German, Bill spoke

Spanish and Portuguese well, a great aid to field work, and was a thorough and methodical collector, pressing even the most tangled vines carefully. Over his career, Bill collected close to 14,000 plants under his own numbering sequence and others when he llected under the numbers of his collaborators. During his career of over four decades, Bill served as major advisor to 16 doctoral students, most of whom are still active in various botanical endeavors. He had a very keen eye for detail, a trait that served him well in editing eight volumes of Rogers McVaugh's Flora Novo-Galiciana. Although Bill published on the fern genus Elaphoglossum and for his $\mathrm{Ph} . \mathrm{D}$. thesis worked on the genus Crusea (Rubiaceae), his passion remained active in research as Professor and Curator Emeritus until shortly before his death.

All aspects of botany intrigued him, yet he was most drawn to systematics and floristics. During his many seasons of field work throughout Latin America, he particularly valued the friendships he formed with his hosts and collaborators. He was an expert of the flowering plant family Malpighiaceae and the flora of western Mexico, the latter largely in collaboration with his former mentor Rogers McVaugh. His scholarly contributions and his commitment to teaching and guiding graduate students were recognized with numerous awards, including the Faculty Recognition Award (University of Michigan, 1978-79), the Asa Gray Award (American Society of Plant Taxonomists, 2008), and the Robert Allerton Award for Excellence in Tropical Botany (National Tropical Botanical

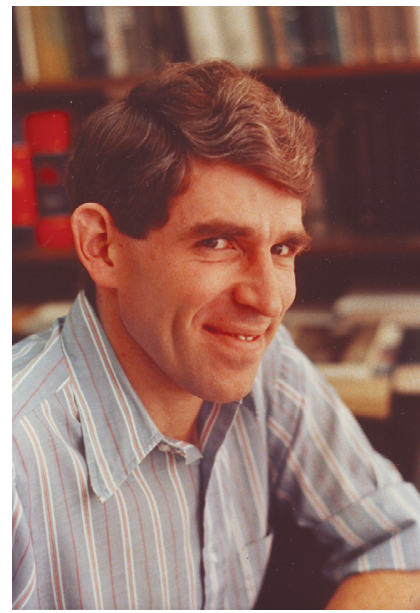

A younger Bill in 1978. Photo by George Proctor.
Garden, 2007). In his honor, colleagues and former students established the William R. Anderson Graduate Student Research Grant Fund (American Society of Plant Taxonomists, 2002).

Bill also had a strong interest in nomenclature and served on the Committee for Spermatophyta, International Association for Plant Taxonomy, 19872000. He also gave substantial service to the American Society of Plant Taxonomists, as a participant on several committees, as Council Member (1990-1992), and as President (1993-1994). was studying the systematics of the Malpighiaceae, on which he authored 69 articles, spanning floristic, monographic, and phylogenetic approaches, the last in close collaboration with Charles C. Davis (Harvard University). At the time of his death, Bill was working on treatments of the family for numerous Flora projects in the New World as well as on a book on all of the genera of the Malpighiaceae. He had hoped to complete his work on the comprehensive Malpighiaceae website (http://herbarium.lsa.umich.edu/malpigh/index.html), assembled by Bill, his wife Christiane Anderson, also a student of Malpighiaceae, and Charles C. Davis, of Harvard University.

Paul E. Berry, Richard Rabeler \& Anton Reznicek University of Michigan Herbarium, 3600 Varsity Drive, Ann Arbor, Michigan 48108-2228,U.S.A.; peberry@umich.edu

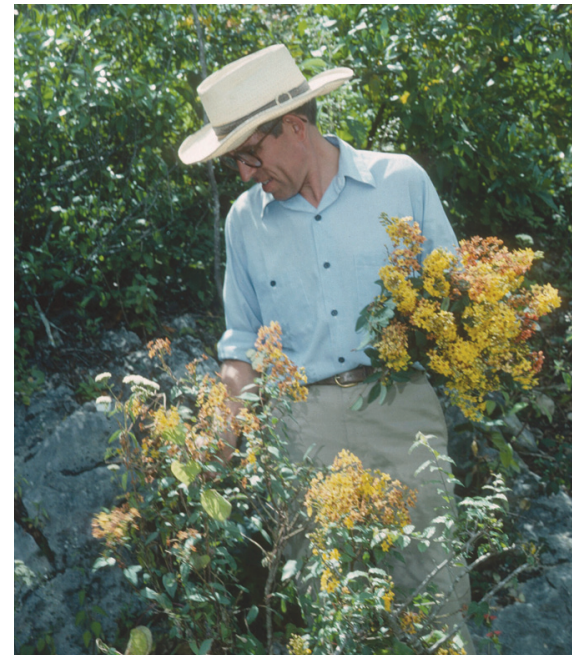

Bill in Chiapas, Mexico, in 1988 collecting the type specimen of Galphimia speciosa C.E. Anderson. Photo by Tom Daniel. 